\title{
Study of Quality Medicinal Plants Bark Walnuts and Extract from it
}

\author{
Strelyaeva AV, Lezhava DI*, Luferov AN, Kuznetsov RM, Bobkova NV, Lazareva YuB, Kostikova EN
}

Strelyaeva AV, Lezhava DI*, Luferov AN, Kuznetsov RM, Bobkova NV, Lazareva YuB, Kostikova EN

Sechenov First Moscow State Medical University (Sechenov University), Moscow, RUSSIA.

\section{Correspondence}

\section{Lezhava DI}

Sechenov First Moscow State Medical University (Sechenov University), Moscow, RUSSIA.

Phone no: +79035371600

E-mail: dianos1993@mail.ru

History

- Submission Date: 24-11-2019.

- Review completed: 19-12-2019;

- Accepted Date: 02-01-2020

DOI : 10.5530/pj.2020.12.44

Article Available online

http://www.phcogj.com/v12/i2

\section{Copyright}

(C) 2020 Phcogj.Com. This is an openaccess article distributed under the terms of the Creative Commons Attribution 4.0 International license.

\begin{abstract}
Objective: The bark of walnut is currently poorly understood and is not represented in the Russian State Pharmacopeia. The purpose was to study the quality indicators medicinal plants walnut crust and extracts therefrom were studied: moisture content, total ash, ash insoluble in $10 \%$ hydrochloric acid feedstock walnut crust; content of tannins and juglone in walnut crust; GC-mass spectrometric study of the composition petroleum extract from the bark of a walnut. Materials and Methods: Microscopy was prepared by the pharmacopoeial method. The chemical composition of the petroleum extract was investigated by chromatomass spectrometry. Results: The content of glycosides amount in terms of gidroyuglone glucoside and absolutely dry RL was $5.30 \pm 0.15$. Humidity was $9,41 \% \pm 0,21$. total ash content was $10,18 \% \pm 0,1$. The ash content insoluble in $10 \%$ hydrochloric acid was $4.8 \pm$ 0.16 . Gas chromatography-mass spectrometry method in petroleum extraction from the bark of walnut were identified following compounds: oktadetsilgeksanoat (28\%) of 4-isopropenyl1-methyl-2-cyclohexenol-1 (38\%), cineole (1,6\%), thujone $(0.7 \%)$, camphor $(16.6 \%), 2$ benzamidoantrahinone $(0.45 \%), 4,5$ - dihydroxy - 3,4 - dihydro - $1(2 \mathrm{H})$ - naftalenon $(6.4 \%)$ ethyl ester of palmitic acid (8.25\%) Toxic effects petroleum extract was $\mathrm{TD}_{50}=2,5$. Chronic absent. All mice in the experimental group had diarrhea. It was established that the extraction has petroleum anthelmintic properties at askaridioze. Conclusions: The analysis of petroleum extraction from walnut partitions was carried out, the content of basic biologically active substances was revealed. The main anatomical and diagnostic signs of walnut bark walls were studied.
\end{abstract}

Key words: Juglans regia, Total ash, Toxic effect.

\section{INTRODUCTION}

In the State Pharmacopoeia of the world necessarily present medicinal herbs morphological groups bark. ${ }^{1}$ Widely known for such raw materials as oak bark, buckthorn bark, bark viburnum, cinnamon bark, and others. The bark of the walnut is a medicinal plant raw materials, which is widely used in folk medicine as an anthelmintic funds, however, this raw material is currently poorly understood and is not represented in the pharmacopeia. ${ }^{2}$ However, medicinal herbs - walnut bark is widely used in folk medicine. The bark of walnut harvested from young branches of a walnut with a diameter of not more than $3 \mathrm{~cm} .{ }^{3}$ Young branches are cut during the formation of the tree crown, with no harm to the plant is not applied. The raw material is harvested, dried and further can be used as a drug in traditional medicine. ${ }^{4}$ Currently, the State Pharmacopoeia of the Russian Federation there is no pharmacopoeial article on medicinal plant raw materials - bark of walnut. ${ }^{5,6}$ Thus, the study of indicators of quality of medicinal plants bark of walnut is relevant.

The purpose was to study the quality indicators medicinal plants walnut crust: humidity, total ash, ash insoluble in 10\% hydrochloric acid; juglone content walnut crust; GC-mass spectrometric study of the composition petroleum extract from the bark of a walnut. ${ }^{7}$

\section{MATERIALS AND METHODS}

As the test material used the bark of walnut harvested from young branches of plants growing in the Kursk region. The bark is harvested in the beginning of sap flow of plants. ${ }^{1}$

Moisture, total ash, ash insoluble in $10 \%$ hydrochloric acid and tannin content determined by the method of the fourteenth edition of State Pharmacopoeia of the Russian Federation. Quantitative determination juglone in the feed was carried out by spectrophotometry. ${ }^{6}$

Analysis glycosides amount in terms of gidroyuglone glucoside in Juglans regia cortex was carried out according to the method of C. Daglish: about $1.0 \mathrm{~g}$ (accurately weighed) RL crushed, passing through a sieve of $1 \mathrm{~mm}$, placed in a flask with $100 \mathrm{ml}$ capacity lapped stopper, was added $50 \mathrm{ml}$ of alcoholic solution of hydrochloric acid $0.27 \mathrm{~mol} / \mathrm{l}$ and was stirred for 30 minutes on a magnetic stirrer. Vieira V. et al., 2019) Extract was filtered into a volumetric flask with $100 \mathrm{ml}$ of a paper filter "red tape", was adjusted to the mark with an alcoholic solution of hydrochloric acid $0.27 \mathrm{~mol} / \mathrm{l}$, was stirred. $2 \mathrm{ml}$ of the resulting solution was transferred into a volumetric flask of $25 \mathrm{ml}$, adjusted to the mark with the same solution, stirred and the absorbance was measured at SF-2000 spectrophotometer at a wavelength of 341 
$\mathrm{nm}$ in a cuvette with a working layer thickness of $1 \mathrm{~cm}$ with respect to hydrochloric acid of $0.27 \mathrm{~mol} / \mathrm{l}$. The content of glycosides amount in terms of gidroyuglona glucoside $(\mathrm{X})$ as a percentage carried by the formula:

$X=\frac{A \cdot 50 \cdot 25 \cdot 100}{A_{1 C M}^{1 \%} \cdot 1 \cdot a \cdot 2 \cdot(100-W)}$

where A - the absorbance of the test solution;

$l$ - the thickness of the working layer of the cell in $\mathrm{cm}$;

but - RL weighed in grams;

$W$ - RL humidity,\%;

- Specific Absorption gidroyuglone glucoside index 174.2.

Petroleum extract assayed for apparatus from Agilent Technologies, USA. The analysis used a standard injection volume - $1 \mathrm{ml}$. Injector Temperature $-250^{\circ} \mathrm{C}$. interface temperature was $280^{\circ} \mathrm{C}$. The carrier gas was helium, flow rate $-1 \mathrm{ml} / \mathrm{min}$. [10, 11]. Software - ChemStationE 02.00. Identification component composition (qualitative analysis) was carried out on the complete library of mass spectra of the NIST-05. The content ratio of mixture components (a quantitative analysis) was determined by calculating the ratio of the areas of the chromatographic peaks (by simple normalization).

\section{RESULTS AND DISCUSSION}

Fresh feedstock is a trough pieces of bark and a length 5-6 cm., A thickness of about 2-3 mm. The outer surface of the crust with smooth transverse wrinkles (Figure 1). There are lenticels rounded shape. The inner surface is smooth bark. At the edge of the fiber fracture.Color brown crust on the outside and a greyish-brown, inside yellowish flesh. Odor weak crust when wetted with water is not amplified. The taste of water extract is bitter. The dried feedstock is a trough pieces of bark, some rolled tube and a length of $5-6 \mathrm{~cm}$., about $2-3 \mathrm{~mm}$ thick. The outer surface of the crust with smooth transverse wrinkles (Figure 1). There are lenticels rounded shape. The inner surface is smooth bark. At the edge of the fiber fracture. Color outside brown bark and grayish-brown inside. yellowish flesh, light brown. Odor weak crust when wetted with water is not amplified. aqueous extract bitter taste.

The experimental results are statistically processed using Student's t test, presented in Table 1.

As follows from the data presented in the table, the content of glycosides amount in terms of gidroyuglone glucoside and was absolutely dry RL5.30 \pm 0.15 .

The disadvantage of this method is the fact that analyzes the juglone in reduced form - very unstable, easily oxidized. Furthermore, analytical wavelength used is not specific for gidroyuglone, in this area, many phenolic compounds also have a maximum light absorption.

Chromato-mass-spectrometry analyzed hydrocarbon extract obtained based walnut crust, wherein about sixty compounds have been identified. 8 were able to identify compounds related to raw walnut, since most major components of the petroleum hydrocarbon shield the active ingredients of the extract from the bark of a walnut (Figure 2).

Acute and chronic toxicity of petroleum extract from the bark of walnut were studied. The experiments were carried out on white linear mice. It was not possible to establish the lethal dose..$^{8-11}$ was determined toxic doses (mice manifested in a number of diarrhea $\mathrm{TD}_{50}=2,5$ ). Experimental animals received the drug inside the maximum possible dose based on the capacity of the stomach experimental animal. The death of experimental animals has not been registered. All test animals in the experimental group appeared diarrhea. Studied the
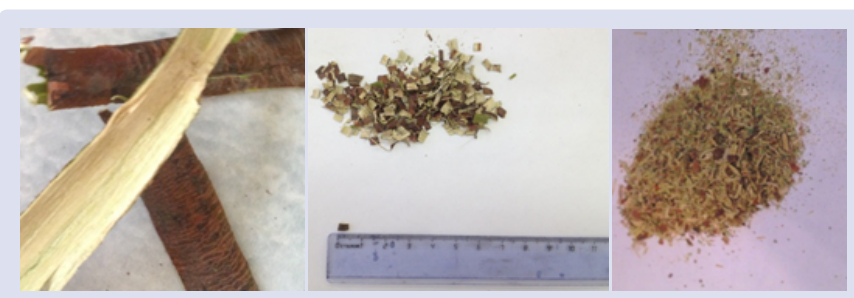

Figure 1: The bark of walnut.

A - Whole raw material; B - Shredded raw materials; C - Walnut bark powder

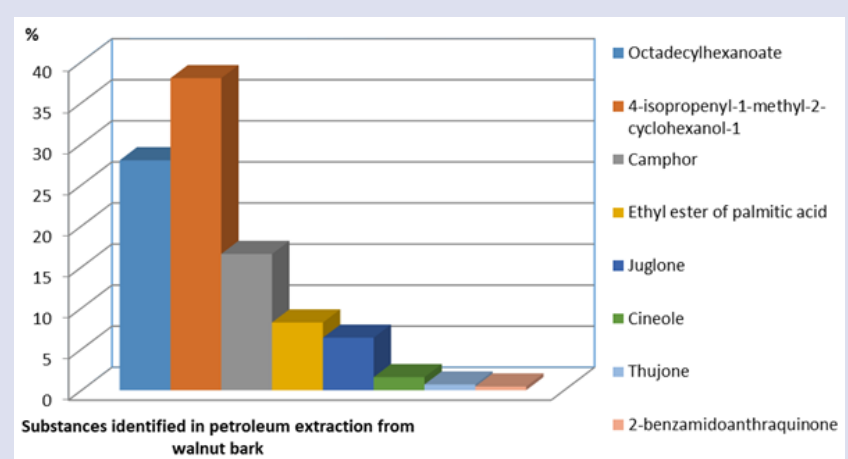

Figure 2: Analysis of petroleum extraction from walnut bark.

Table 1: Contents of gidroksiyuglone.

\begin{tabular}{lllllll}
\hline $\mathrm{Xi}, \%$ & $\mathrm{X}$ & $\sigma 2$ & $\sigma$ & $\mathrm{P}$ & $\mathrm{T}(\mathrm{P}, \mathrm{F})$ & $\Delta \mathrm{X}$ \\
\hline 5,$334 ; 5,231 ; 5,377 ;$ & 5.30 & 0.0049237 & 0.070169082 & 95 & 5,334 & 0.15 \\
5,$344 ; 5.223$ & & &
\end{tabular}

Table 2: Humidity.

\begin{tabular}{lllllll}
\hline $\mathrm{Xi}, \%$ & $\mathrm{X}$ & $\sigma 2$ & $\sigma$ & $\mathrm{P}$ & $\mathrm{T}(\mathrm{P}, \mathrm{F})$ & $\Delta \mathrm{X}$ \\
\hline $9.30 ; 9.45 ; 9.34 ;$ & \multirow{2}{*}{0.41} & 0.007186667 & 0.08477421 & 95 & 9.405 & 0.21 \\
$9.36 ; 9.51 ; 9.48$ & & & &
\end{tabular}

Table 3: Total ash.

\begin{tabular}{ccccccc}
\hline $\mathrm{Xi}, \%$ & $\mathrm{X}$ & $\sigma 2$ & $\sigma$ & $\mathrm{P}$ & $\mathrm{T}(\mathrm{P}, \mathrm{F})$ & $\Delta \mathrm{X}$ \\
\hline $10.12 ; 1010,19,22 ;$ & \multirow{2}{*}{0.18} & 0.001546667 & 0.039327683 & 95 & 10.185 & 0.1 \\
\hline $10.14 ; 10.21 ; 10.18 ;$ & & & & & & \\
\hline
\end{tabular}

Table 4: Ash insoluble in $\mathbf{1 0 \%}$ hydrochloric acid.

\begin{tabular}{ccccccc}
\hline $\mathrm{Xi}, \%$ & $\mathrm{X}$ & $\sigma 2$ & $\sigma$ & $\mathrm{P}$ & $\mathrm{T}(\mathrm{P}, \mathrm{F})$ & $\Delta \mathrm{X}$ \\
\hline $\begin{array}{c}4.8 ; 4.75 ; 4.82 ; 4.91 ;, 4.78 ; \\
4.84\end{array}$ & 4.8 & 0.00122 & 0.034928498 & 95 & 4.8 & 0.16 \\
\hline
\end{tabular}

pharmacological activity petroleum extract from the bark of a walnut. In experiments on chickens infected ascaridosis anthelmintic activity was observed. All of the experimental animals nost free from parasites.

\section{CONCLUSIONS}

1.When description external signs medicinal plant raw material walnut crust following diagnostic features were found: fresh feedstock is a trough pieces of bark and a length 5-6 cm., A thickness of about 2-3 $\mathrm{mm}$. The outer surface of the bark is smooth with transverse wrinkles. There are lenticels rounded shape. The inner surface is smooth bark. At the edge of the fiber fracture. Color brown crust on the outside and a greyish-brown, inside yellowish flesh. Odor weak crust when wetted with water is not amplified. aqueous extract bitter taste. The dried feedstock is a trough pieces of bark, some rolled tube and a length of 5-6 $\mathrm{cm}$., About 2-3 mm thick. The outer surface of the crust with smooth 
Table 5: Compounds in petroleum extraction from the bark of walnut.

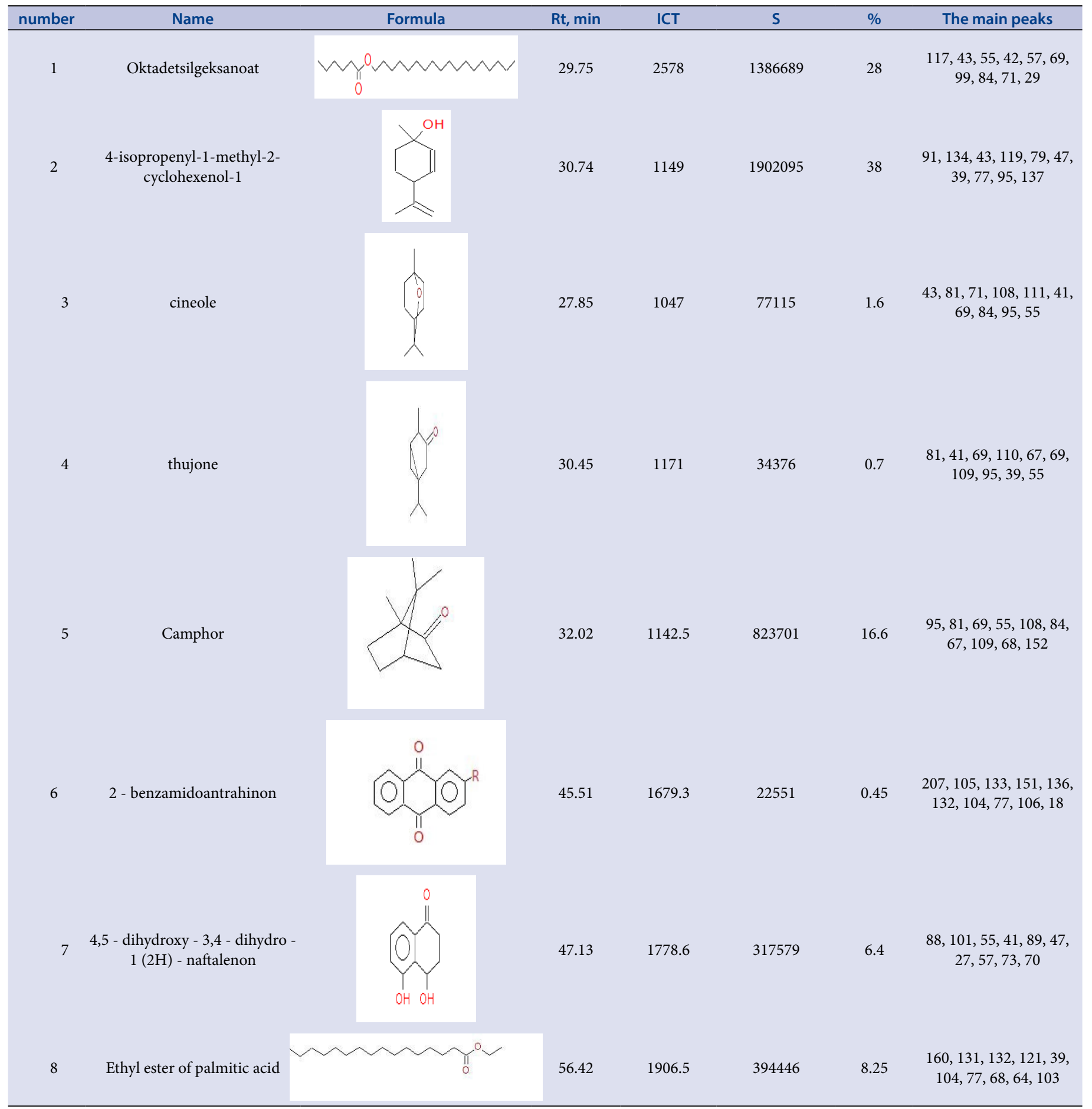

transverse wrinkles (Figure 1). There are lenticels rounded shape. The inner surface is smooth bark. At the edge of the fiber fracture. Color outside brown bark and grayish-brown inside. yellowish flesh, light brown. Odor mild.

2. The content of glycosides amount in terms of gidroyuglone glucoside and absolutely dry RL was $5.30 \pm 0.15$. Humidity was $9,41 \% \pm 0,21$. total ash content was $10,18 \% \pm 0,1$. The ash content insoluble in $10 \%$ hydrochloric acid was $4.8 \pm 0.16$.

3. The method of gas chromatography-mass spectrometry in petroleum extraction from the bark of walnut were identified following compounds: oktadetsilgeksanoat (28\%) of 4-isopropenyl-1-methyl- 2-cyclohexenol-1 (38\%), cineole (1.6\%), thujone (0.7\%), camphor (16.6\%), 2 - benzamidoantrahinon (0.45\%), 4,5 - dihydroxy - 3,4 dihydro - $1(2 \mathrm{H})$ - naftalenon (6.4\% ), ethyl palmitate $(8.25 \%)$.

4. Toxic effects petroleum extract was $\mathrm{TD}_{50}=2,5$. Chronic absent. All mice in the experimental group had diarrhea.

5. It is established that petroleum extraction has anthelmintic properties at askaridioze.

\section{FINANCIAL SUPPORT AND SPONSORSHIP}

Nil. 


\section{CONFLICTS OF INTEREST}

There are no conflicts of interest.

\section{ACKNOWLDGEMENT}

Supported by the Russian Academic Excellence Project 5-100 (Sechenov University).

\section{REFERENCES}

1. Yan M, Chen M, Zhou F, Cai D, Bai H, Wang P, Ma Q. Separation and analysis of flavonoid chemical constituents in flowers of Juglans regia L. by ultrahigh-performance liquid chromatography-hybrid quadrupole time-of-flight mass spectrometry. Journal of Pharmaceutical and Biomedical Analysis. 2019;164:734-41

2. Gao P, Liu R, Jin Q, Wang X. Comparative study of chemical compositions and antioxidant capacities of oils obtained from two species of walnut: Juglans regia and Juglans sigillate. Food Chemistry. 2018;279:279-87.

3. Dolatabadi S, Moghadam HN, Mahdavi-Ourtakand M. Evaluating the antibiofilm and antibacterial effects of Juglans regia L. extracts against clinical isolates of Pseudomonas aeruginosa. Microbial Pathogenesis. 2018;118:285-9.

4. Mollica A, Zengin G, Locatelli M, Stefanucci A, Macedonio G, Bellagamba G, et al. An assessment of the nutraceutical potential of Juglans regia $L$. leaf powder in diabetic rats. Food and Chemical Toxicology. 2017;107:554-64
5. Abdoli M, Dabaghian FH, Goushegir A, Shirazi MT, Nakhjavani M, Shojaii A, et al. Anti-hyperglycemic effect of aqueous extract of Juglans regia L. leaf (walnut leaf) on type 2 diabetic patients: A randomized controlled trial. Advances in Integrative Medicine. 2017;4 (3):98-102.

6. Vieira V, Prieto MA, Barros L, Coutinho JAP, Ferreira ICFR, Ferreira O. Enhanced extraction of phenolic compounds using choline chloride based deep eutectic solvents from Juglans regia L. Industrial Crops and Products. 2018;115:261-71.

7. Abdallah IB, Tlili N, Martinez-Force E, Rubio AGP, Perez-Camino MC, Albouch $A$, et al. Content of carotenoids, tocopherols, sterols, triterpenic and aliphatic alcohols, and volatile compounds in six walnuts (Juglans regia L.) varieties. Food Chemistry. 2015;173:972-8.

8. Hosseini S, Jamshidi L, Mehrzadi S, Mohammad K, Najmizadeh AR, Alimorad $H$, Huseini HF. Effects of Juglans regia L. leaf extract on hyperglycemia and lipid profiles in type two diabetic patients: A randomized double-blind, placebocontrolled clinical trial. Journal of Ethnopharmacology. 2014;152(3):451-6.

9. Raafat K. Phytochemical analysis of Juglans regia oil and kernel exploring their antinociceptive and anti-inflammatory potentials utilizing combined bio-guided GC-FID, GC-MS and HPLC analyses. Revista Brasileira de Farmacognosia. 2018;28(3):358-68

10. Jin YX, Ma XL, Wei HY, Guo XF, Ma GX, Shi LL, et al. Two new diarylheptanoids from the green husks of Juglans regia $L$. and their cytotoxic activities. Phytochemistry Letters. 2019;(32):101-4.

11. Vieira V, Pereira C, Pires TCSP, Calhelha RC, Alves MJ, Ferreira O, et al. Phenolic profile, antioxidant and antibacterial properties of Juglans regia $\mathrm{L}$. (walnut) leaves from the Northeast of Portugal. Industrial Crops and Products. 2019:(134):347-55

\section{GRAPHICAL ABSTRACT}

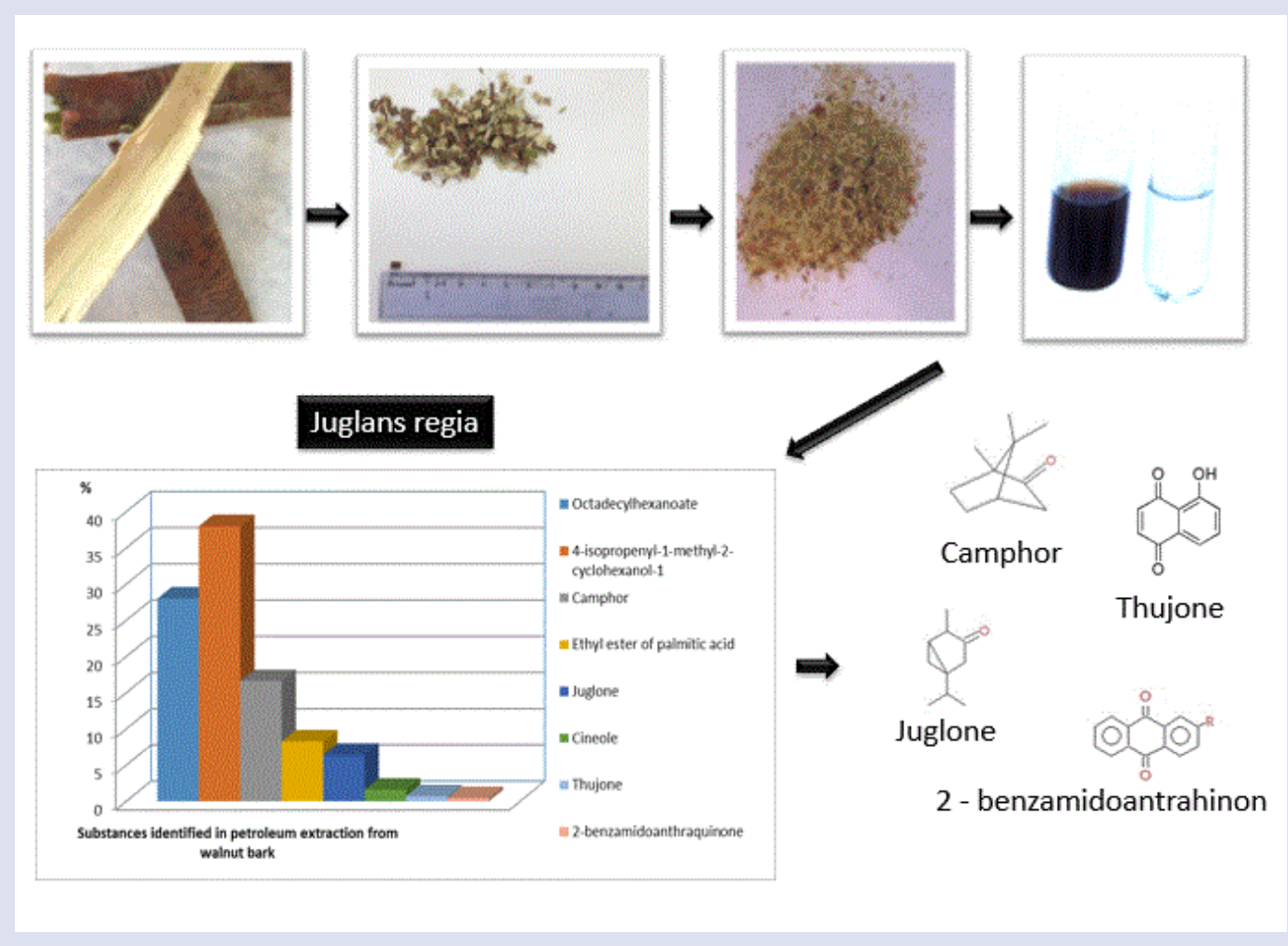

\section{ABOUT AUTHORS}

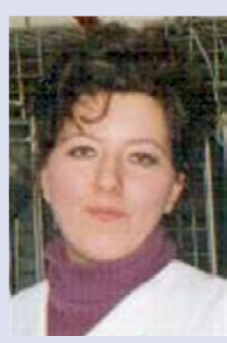

Strelyaeva Angelina Vadimovna - Doctor of Pharmaceutical Sciences, Professor of the Department of Pharmaceutical and Natural Sciences, Institute of Pharmacy named after A.P. Nelyubin Sechenov First Moscow State Medical University. 


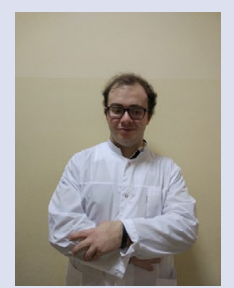

Lezhava Dianos Ivanovich - Postgraduate student of the Department of Pharmaceutical and Natural Sciences, Institute of Pharmacy named after A.P. Nelyubin, Sechenov First Moscow State Medical University.

Kuznetsov Roman Mikhailovich-PhD in Chemistry, Leading Researcher at the Laboratory of Pharmacokinetics and Metabolum Analysis of Sechenov First Moscow State Medical University.

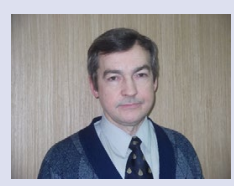

Luferov Alexander Nikolaevich - PhD in Biological Sciences, Head of the Department of Pharmaceutical and Natural Sciences, Institute of Pharmacy named after A.P. Nelyubin Sechenov First Moscow State Medical University

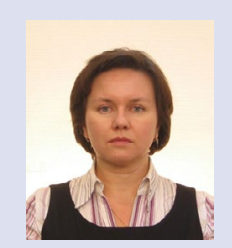

Bobkova Natalia Vladimirovna - Doctor of Pharmaceutical Sciences, Professor of the Department of Pharmaceutical and Natural Sciences, Institute of Pharmacy named after A.P. Nelyubin, Sechenov First Moscow State Medical University.

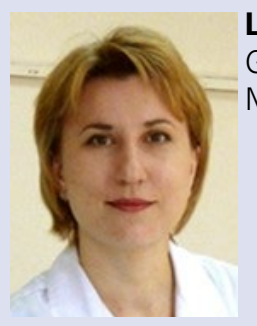

Lazareva Yulia Borisovna - Candidate of Medical Sciences (PhD), Docent of the Department of Biology and General Genetics Institute of Clinical Medicine named after N.V. Sklifosovsky, Sechenov First Moscow State Medical University, lecturer of Resource Center "Medical Sechenovsky Preuniversary"

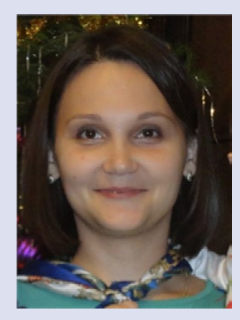

Kostikova Elena Nikolaevna - PhD in Pharmaceutical Sciences, Assistant of the Department of Pharmaceutical and Natural Sciences, Institute of Pharmacy named after A.P. Nelyubin, Sechenov First Moscow State Medical University.

Cite this article: Strelyaeva AV, Lezhava DI, Luferov AN, Kuznetsov RM, Bobkova NV, Lazareva YuB, et al. Study of Quality Medicinal Plants Bark Walnuts and Extract From it. Pharmacog J. 2020;12(2):282-6. 